\title{
Resurrecting Rome. Liturgy and Rome's Second Revival
}

\begin{abstract}
Liturgy is one of the more underestimated entries of the Gregorian reform. Surely, this is due to the difficulty of getting a clear view of concrete and detailed liturgical evolutions and renewals. It seems, however, to have been one of the more important elements at stake during the short period of the bitter and hard confrontations between the leading layers of the Church around 1100. Besides, between about 1050 and 1150, Rome saw an intense building activity of new churches according to new plans that seem to have been partly dictated by liturgical renovations. Notably, Pope Innocent II seems to have realized the importance of liturgy as a weapon to be used against his ecclesiastical and secular opponents. Thanks to the remarkable Liber politicus by Benedict the Canon (around 1140), we can have some ideas of the way Innocent II used liturgy as a means to install his own imperial papacy. My contribution will have a closer look at Benedict's Liber politicus in its literary context as a means to reimagine Rome. The Liber will prove to be much more than a liturgical manual or a strange collection of disparate writings. Behind it lies a strong view of the political role of the papacy and of liturgy as a means to achieve and express papal supremacy.
\end{abstract}

\section{By way of introduction: a pontifical solemnity}

Either in Spring or in Autumn 1131, Pope Innocent II, voluntarily exiled to France, paid a visit to the abbey of Clairvaux, whose abbot he had come to know as one of his most fervent and effective supporters in his claim for recognition. ${ }^{1}$ As fitted the prestige of their guest, the monks came out to meet him and to accompany him towards the monastery. A meal was served that excelled in frugality. Actually, everything they saw struck the visitors because of its austere poverty. The papal visit culminated in the Holy Mass celebrated by the entire community and conducted by the pope himself. Here something happened, induced by the devil, as our source stresses, for he had been waiting for this opportunity. Let me quote the passage from the second book of the life of Bernard, the abbot of Clairvaux (II.7), written soon after Bernard's death in 1153 by Arnold, abbot of Bonneval:

\footnotetext{
${ }^{1}$ The sources that mention the visit place it on the way back from Liège where Innocent met Lothar III in March 1131 and received the Emperor's recognition. Verdeyen 2011, 94; Heller 1880, (III.24) 99. Bernard's $19^{\text {th }}$-century biographer Elphège Vacandard thinks this too difficult, seen Innocent's itinerary, and proposes a date later in the year when Innocent stayed at Auxerre between July 26 and September 24: Vacandard 1927, vol. I, 314.
} 
While in the choir they were singing the psalms with joyful devotion and many of the cardinals present enjoyed the sight and the music, a horrible panic took possession of some of the brothers. For one of them, who had been busier than the others, spoke out in these blasphemous words: 'Say all: I am Christ.' Most of the others, terrified and trembling, took refuge with the Holy Father's presence. But he turned to them saying: 'Pray.' Then, in all silence, he led those out who seemed most upset and calmed them. The wicked one who tried to change a meeting of piety into a theatre and to ridicule a school of innocence proved incapable to destroy the general estimation of these religious men, as he had hoped. He rather betrayed himself and proved his attempts to be powerless. Everything was calmed down with such speed that even to those who stood nearby remained hidden what had happened. That doomed enemy of humankind was quickly beaten. He proved impotent to infer the damage upon them as he had planned and he did not even manage to make it known to them. ${ }^{2}$

The incident has not yet received any attention as far as I know. All scholarly research that occupied itself with this passage remained focused upon the impression the Cistercian austerity made on the ecclesiastical dignitaries and that contrasted so sharply with how they had been received at other places. ${ }^{3}$ The passage thus normally serves to illustrate the sober aesthetics, which are considered so characteristic of Bernard's project. Or it serves to oppose the frugality of the reformed monastic movement to the opulence that is associated with Innocent's suite and lifestyle. The attention, therefore, never goes beyond the meeting of the two processions, the monastic on the one hand in all its humility and poverty, the papal one, on the other, which our source does not describe. But, thanks to the much more known description by Suger in his Life of Louis VI (ca. 1140), we know how Innocent II travelled through France, notably how he prepared for a pontifical Mass (cap. 32):

Very early the next morning he went out as if in secret to the church of St. Denis de l'Estrée, with a large number of companions. There they made preparations in the Roman way, they clothed him in splendid attire and set on his head a mitre like a helmet, a truly imperial adornment, with a golden crown surrounding it; then they led him forth, mounted on a white horse with a saddle cloth, while they went before him two by two, wearing rich robes, riding horses of various colours but all with white saddle cloths, and singing festive hymns. The barons who held in fee of our church and the noble castellans accompanied him on foot, holding his horse's reins like humble grooms. Men went before them

\footnotetext{
${ }^{2}$ Verdeyen 2011, 94-95: "Inuidit diabolus et seruorum Dei gloriam quos tanti hospitis nobilitabat praesentia, ferre non ualens, dum in choro alacriter psallerent et deuote, praesentibus etiam nonnullis ex cardinalibus, qui in auditu et aspectu eorum delectabantur, aliquantos fratrum horribili pauore turbauit. Nam et unus prae ceteris occupatus, blasphema quaedam uerba locutus est: 'Dicite': inquiens, 'Ego sum Christus', et alii plures territi et tremebundi, ad beati patris uestigia confugerunt. At ille conuersus ad ceteros: 'Orate', inquit, ac deinceps sub silentio eos qui turbati uidebantur eduxit atque compescuit; ut nequissimus ille, qui conuentum pietatis transferre conabatur in theatrum, et scolam innocentiae in derisum, non, ut putabat, aestimationem religiosorum hominum corrumpere posset, sed se proderet et conatus suos experiretur infirmos. Tanta siquidem celeritate omnia sunt sedata, ut personas illas, quae prope astabant, omnino latuerit quod acciderat. Et malignus hostis uelociter increpatus, non modo scandalum eis quod parabat inferre nequiuerit, sed nec ad illorum notitiam rem perferre". All translations are mine if not otherwise mentioned.

${ }^{3}$ Most recently, Astell 2006, 64-65.
} 
throwing a shower of coins to scatter the crowd which blocked the way. The royal highway blazed with embroidered cloths attached to posts and branches. ${ }^{4}$

We have to imagine this pomposity of visit and celebration sharply contrasting to the austerity of the monastic surroundings at Clairvaux. The tension between the unseen wealth and exuberance of the papal celebration and the extreme poverty the monks were accustomed to 5 may offer a sufficient explanation of the bizarre and, according to Bernard's biographer, diabolic reaction of the simple monk, of whom it is explicitly mentioned that he was more than the others occupied in making all go well. The small anecdote that opens the second book of Bernard's life thus offers us a very rare insight in how liturgy could work upon the mind of those participating. It shows us the transformational power liturgy could have.

Then, what happened actually? The words of the monk are remarkable: Say: I am the "Christ" - Dicite: Ego sum Christus. The monk does not want to express what might be all too easily understood: that he himself did assimilate with the Saviour. No, he encourages those around him to confess their collective unity with Christ: Let us say with one voice: I am the "Christ". Here, at this place, the oratory of Clairvaux, and at this moment, during Holy Mass, celebrated by the head of the Church, in the display of all this unaccustomed pontifical splendour, the colours, the jewels, the gold, the flickering lights of the candles, the incense undoubtedly, and, not to forget, the music of the psalms, this monk experienced what liturgy strives to achieve: unity of the faithful with the divine Spouse, i.e. transformation of the community of individuals into the body of the Christ.

Do we have any reason to doubt the historicity of the anecdote? After all, how could Bernard's biographer, who never was monk at Clairvaux, know of the event when not even those present noticed it? Moreover, the anecdote appears at the beginning of his account of Bernard's life and it announces the theme that will play throughout his entire book, in which Bernard is presented as a human counterpart of the workings of the Divine Trinity. ${ }^{6}$ Nonetheless, the biographer situated the story within Innocent's visit to Clairvaux, thus giving it a highly psychological credibility because of the impression this pope's ostentation of magnificence and pomp made upon his French hosts, as can be seen in Suger's account quoted earlier.

\footnotetext{
${ }^{4}$ Waquet 1964, 263-264: "Summo mane vero extrinseca via ad ecclesiam Martirum in Strata, cum multo collateralium collegio quasi secreto commeavit, ibique more romano seipsos preparantes, multo et mirabili ornatu circumdantes, capiti eius frigium, ornamentum imperiale, instar galee circulo aureo circinatum imponunt, albo et palliato equo insidentem educunt, ipsi etiam palliati equos albis operturis variatos equitantes, odas personando festive geminati procedunt. Barones vero ecclesie nostre feodati et castellani nobiles, stratores humillimi, pedites eum equitantem freno deducebant. Quidam etiam previi copiosam monetam, ut turbam impedientem removerent, iactitabant. Via autem regia et salicibus et fixis stipitibus preciosis palliis rutilabat". Translation by Dunbabin: https://sourcebooks.fordham.edu/basis/suger-louisthefat.asp (last consulted on October 25, 2018).

${ }^{5}$ The poverty of Clairvaux has been stressed in William of St. Thierry's biography of Bernard and has since been repeated in scholarly literature as a recurrent topos. Serious investigation can be found in Fossier, 1953, 88-93.

${ }^{6}$ I have elaborated the different lines and themes in the biographical corpus on Bernard in my $\mathrm{PhD}$ dissertation (in Dutch), defended in May 2000. This part still waits for being reworked into a publication.
} 


\section{The Liber politicus of Benedict the Canon}

Before approaching the core theme of this contribution, let us yet regard shortly one of the elements that made the poor monk lose his senses. According to the biographer, it happened while they were singing the psalms. Now, in 1131, the Cistercians were bound to the reformed hymnody as imposed by Stephen Harding, then still ruling abbot of Cîteaux. In his wish to return to the true Ambrosian hymnody and to what he considered to be the true Gregorian melodies, Stephen had relied on traditions of Milan and Metz, although they were incompatible with the melodies as used in Burgundy and the other regions of France. Only after Stephen's death in 1134, the General Chapter ordered Bernard to induce a reform of the liturgical music. ${ }^{7}$

Innocent had his own papal choir, the schola, on which much has been written. Likewise, much has been written on the music they performed. ${ }^{8}$ Most likely, it seems to have been a form of the Old Roman Chant. In order to understand the monk's confusion, it seems important that the event happened at a moment of chanting. It not only indicates the sharp contrast between the Cistercian and the Papal Chant but it may be seen as a proof of the importance Innocent attached to music and the musical aspect of liturgy.

We still have a source of prime interest on liturgy under Innocent, the Liber politicus by Benedict the Canon. The Liber was written in the early 1140s, after the ending of the papal schism that had divided the Church for most of the 1130s between the supporters of Innocent II and those of Anaclet II. Benedict has been for some time at the centre of scholarly interest, both for liturgists because of the Ordo Romanus XI we find in his book, and for archaeologists because of the strange text that in the three manuscripts that allow us the reconstruction of the Liber, ${ }^{9}$ is connected to the Ordo and that is known under the name of the Mirabilia Urbis Romae. ${ }^{10}$

My approach to Benedict's text, however, will be from a literary point of view, which in the first place means that I will have a look at what we know that Benedict wrote, i.e. a BOOK, the LIBER politicus. For, around 1100, we actually see the revival of the idea of a book as a compositional unit. ${ }^{11}$ Elsewhere I explained this as the disconnection of the book in its materiality, i.e. the codex, from the book in its conceptuality, i.e. the internal composition as a closed and not dissoluble entity. It means in the first place that a writer starts to collect his single writings and to compose them into a book, i.e. not as a loose collection of individual items but as obeying to a compact overarching idea, thus making it into what has been called a macro-text. ${ }^{12}$

\footnotetext{
${ }^{7}$ On the complex history of the Cistercian Hymnal, see Waddell 1984, 3-105.

${ }^{8}$ See for the musical rivalry between the Lateran and the papal schola of St. Peter's with further bibliography: Dyer 2008, 134-135.

${ }^{9}$ Cambrai 554 ( $12^{\text {th }}$ century), Valicellanus F.73 and Vaticanus 5348 (both $14^{\text {th }}-15^{\text {th }}$ century).

${ }^{10}$ See in this volume the contributions by Dale Kinney and John Romano with additional bibliography.

${ }^{11}$ Verbaal 2017; Verbaal 2018. There has been no scholarly attention given to this phenomenon of the reemergence of the book as a compositional idea but it fits in with other developments as they take place in the late $11^{\text {th }}$ and $12^{\text {th }}$ century as the breaking down of the scriptio continua and its presumed connection to a culture of silent reading, or the division of texts into numbered paragraphs and chapters with the elaboration of indexes. See the studies of Saenger 1997 and of Rouse, Rouse 1991.

${ }^{12}$ Verbaal 2018; Santi 2014, 145-154.
} 
Probably not the first, but one of the earliest ones to do so was Hildebert of Lavardin, the leading member of the so-called Loire poets. We can recognize his compositional talents in the collections he made both of his letters and of his poems. These last years, several studies have pointed to the internal coherency notably of the late $11^{\text {th }}$ - and early $12^{\text {th }}$-century authors' compositions of their epistolary books. ${ }^{13}$ For that reason, this contribution rather wants to clarify why Benedict's work ought first of all to be regarded as a book and thus considered as a closed composition. Both by editors and scholars, Benedict's texts have hardly been studied in their coherency but only as disparate elements without any connection. ${ }^{14}$ My primary question when approaching the Liber politicus thus asks for the book as a unit, containing so to say a macro-text with its own message.

\section{Do the contents make a book?}

As scholarly attention has rather been limited to two of the different parts that constitute Benedict's Liber politicus, I will first give a brief overview of its content as it was reconstructed by the editors. ${ }^{15}$ For, the Liber is only transmitted in an indirect way: either as part of other compilations like the Liber Censuum, as part of which it is edited, ${ }^{16}$ or in very late manuscripts. ${ }^{17}$ Yet, these are the ones that, according to the editors, Fabre, Duchesne, give us the right idea of how the book was composed, notably the manuscript Vallicellanus F. 73, of which the Vatican manuscript seems to be a selective copy.

The editors of the Liber Censuum tried to reconstruct the supposed original composition of Benedict's Liber politicus. According to them, manuscript Vallicellanus F.73 gives the authentic view of it, which they describe as the Ordo with a series of 'appendices'. They take over the sequel as offered by the manuscript: ${ }^{18}$

\section{Dedication Letter by Benedict to Guido de Castello}

2. Ordo Romanus XI

3. Solemnities during which the pope must be crowned

4. Solemnities during which the stationes take place at St Peter's

5. List of popes

6. Retreat of cardinals to their own churches after their ordination

\footnotetext{
${ }^{13}$ von Moos 2006; Haseldine 1997; Haseldine 2001, ix-liii; Ysenbaert 2009 (= 2015). See further my articles on the letter collections of Abelard, Bernard and the Loire school: Verbaal 2014; Verbaal 2015; Verbaal 2017; Verbaal 2018.

${ }^{14}$ As I will explain later, Benedict's Liber is composed out of several elements, of which most scholarly attention is given to the Ordo Romanus XI that makes up the first element and the Mirabilia Urbis Romae that makes up the last part. The intermediary elements have rarely been taken into consideration. One of the reasons can be the way they have been treated by the main editors Fabre, Duchesne who separated them and scattered them over their edition of the Liber Censuum, while even refusing to edit one of the sub-elements. Nonetheless, Fabre, Duchesne considered Benedict's Liber as a unity, which has been contested afterwards by several scholars as Schimmelpfennig 1973 and Miedema 1996, 4-11. Their position is discussed largely by Hamilton 2011, 419-421 and by Accame, Dell-Oro 2004, 18-22. It is fiercely attacked by Kinney 2008 and repudiated on sound arguments by Romano 2010.

${ }^{15}$ Fabre, Duchesne 1905-1910.

${ }^{16}$ Fabre, Duchesne 1905-1910: the Liber is moreover not edited as a unit but dispersed and truncated over the entire edition.

${ }^{17}$ See note 9. The most ancient manuscript is the one from Cambrai, ms. 554, but, according to the editors (preceding note) it offers a less reliable text and it rearranged the contents of Benedict's Liber.

${ }^{18}$ Fabre, Duchesne 1905-1910, vol. 1, 3-4.
} 
7. Laudes to be sung on the days where the pope is crowned

8. Popular festivities during the year

9. Song by the youngest members of the Schola cantorum

10. Mirabilia Urbis Romae

The editors interpreted the title of the book as Liber polyptichus, referring to a kind of register, literally a book with many leaves. When having a look at the list of topics it contains, the title truly seems to cover what it says because the book contains a whole range of seemingly disparate topics, of which the Mirabilia indeed seem the most disparate. When we look more closely at the book in its entirety, however, we see that the Mirabilia actually offer an important clue to understanding the role of liturgy in Innocent's politics.

After the dedication letter, the Book opens with the Ordo that follows the papal ceremonies throughout the Roman churches and basilicas over the year. Much attention is given to the solemnities in St. Peter and to the different processions inside the basilicas and outside through the streets of Rome. Benedict, canon of St. Peter's besides being with all probability cantor of the papal choir, expands largely upon the hymns and antiphons that are sung during these solemnities. But he clearly likes also to depict the splendour that surrounds the pope when leading and participating in the celebrations and processions. ${ }^{19}$

Is it just a coincidence then that his evocation of the papal liturgical year is followed by a list of solemnities in which the pope is crowned $?^{20}$ They seem not only chosen because of the importance of the celebration but in the first place because of the specific dignity derived from the coronation ceremony. These are the moments in which the papal identification with the worldly rulers becomes most obvious. It is almost impossible to give more explicitly expression to the papal equality with, if not supremacy over the Emperor, specifically in the period just after the Concordat of Worms. ${ }^{21}$

By proceeding immediately with the solemnities that have their stationes in St. Peter's the reader gets the impression that St. Peter and the Vatican actually form the papal residence. ${ }^{22}$ Of course, they do not. The Lateran held this position, but the Ordo seems to express also an ongoing rivalry between the great Roman basilicas, in which Benedict voices clearly the preeminence of St. Peter against both St. Maria Maggiore and the Lateran. ${ }^{23}$

Then follows the pope-list. ${ }^{24}$ It is almost complete for the first 40 popes, that is until Innocent I ( $\uparrow 417)$. Only 7 popes are missing. ${ }^{25}$ After him only another 13 popes are mentioned, significantly concluding with Innocent II. Benedict clearly is a strong adherent of this pope, his Lord as he calls him. His partisanship can also be remarked by his leaving out the four popes between Urban II and Innocent II, whose lives had been written some ten years earlier

\footnotetext{
${ }^{19}$ Fabre, Duchesne 1905-1910, vol. 1, 141-164, text on 141-159.

${ }^{20}$ Fabre, Duchesne 1905-1910, vol. 1, 90.

${ }^{21}$ See also Suger's emphasis on the frigium, the mitre, and its secular associations in the quotation from his Life of king Louis VI (n. 4).

${ }^{22}$ Fabre, Duchesne 1905-1910, vol. 1, 90.

${ }^{23}$ See for the rivalry Riccioni 2011, 444 n. 13; Champagne, Boustan 2011, 480 with earlier scholarship in n. 52.

${ }^{24}$ Fabre, Duchesne 1905-1910, vol. 1, 165-170, tekst on 165-169.

${ }^{25}$ Linus (66-78), Pontianus (230-235), Sixtus II (257-258), Marcellinus (296-304?), Julius I (337-352), Liberius (352366), Siricius (384-399).
} 
by an apparent adherent of Innocent's rival, Anaclet II. These lives were incorporated into the Liber Pontificalis. ${ }^{26}$

In the list, most attention is given to those popes that display a truly imperial authority. Saint Peter himself is mentioned for his being the first to issue an ecclesiastical decree, but, of course, the most elaborated pope is Silvester who is mentioned as the builder of the Lateran, of St. Peter's and of St. Paul Outside the Walls. Besides, when Constantine leaves Rome for Constantinople, his separation from Sylvester is given much attention. According to the list, voicing a wide-spread tradition, Constantine handed over to the pope all the imperialia, the imperial insignia, as the white horses and - the crown!

After the list of popes, the Book continues with a number of texts that seem to make a descending move through the members of the Church. First, a short text on the cardinals, then the liturgical songs as they had to be performed by the Schola cantorum on the coronation days, then the popular festivals ending with, again, songs performed by the Schola cantorum, but now by its youngest members. ${ }^{27}$ As to the songs, they address Innocent II as the one who gained Victoria, who earned honour comparable to the Cesars and who reigned the entire universe in St. Peter's name. He also has to protect the Roman arms as did the ancient Emperors. Then, finally, follow the Mirabilia. ${ }^{28}$

\section{Consecrating the Past}

When going through this sequel of texts, it may be argued that the text of the Mirabilia does not appear completely irrelevant to the context. On one hand, the Mirabilia describe the material background to all that precedes in the other texts of the corpus. It shows in what surroundings these festivities and celebrations take place. But on the other hand, the text also depicts the most basic level in the universe of the Roman city: the classical remains, both in their ruins and in their legendary histories. Once again, in view of the post-Investiture Controversy, the Mirabilia seem to push the Emperor as the classical prefiguration of the Pope to the lower levels of the Roman hierarchy.

But to have a good understanding of what the actual meaning of this text is it seems welcome to give a short summary of its content. For the text of the Mirabilia does not form a homogeneous unit: it seems as disparate as the Liber as a whole. Generally, three parts are distinguished: ${ }^{29}$

$\begin{array}{ll}\text { I. } & \text { Descriptio Urbis Romae } \\ \text { II. } & \text { Fabulae variae } \\ \text { III. } & \text { De templis }\end{array}$

\footnotetext{
${ }^{26}$ Paschalis II, Gelasius II, Calixtus II, Honorius II: their lives written by Pandolphus, supporter of Anacletus II, in Duchesne 1892, 296-328.

${ }^{27}$ Fabre, Duchesne 1905-1910, vol. 1, 90-91, 171-174.

${ }^{28}$ Fabre, Duchesne 1905-1910, vol. 1, 262-283, text on 262-273. More recent edition in Valentini, Zucchetti 1946, 17-65. For convenience we use the separate reproduction of Valentini, Zucchetti's text as published by Accame, Dell'Oro 2004. It has to be noticed that the Mirabilia are never mentioned under this name in the text or within the Book. A first trace of the name can be found in the Italian translation around 1250, labelled le miracole de Roma. See Verbaal 2018, 222.

${ }^{29}$ Kinney 2008, 236-237.
} 
It opens with ten short chapters, enumerating successively the walls, the gates, the triumphal arches, the hills, the thermae, the palaces, the theatres, the places where martyrs suffered, the bridges and the cemeteries. ${ }^{30}$

The second part contains a number of largely fictitious stories: the vision of Augustus and the Sibyl, a story about the two marble Dioscuri of the Quirinalis, the story of the bronze equestrian statue of the Lateran - that in contrast to the contemporaneous tradition is explicitly not identified with Constantine the Great -, the building and consecration of the Pantheon, the building of Saint Peter in Vincoli. ${ }^{31}$

This sequel is interrupted after the story of the Dioscuri by a list of courtly officials and by a short chapter with the height of the columns and the Coliseum. ${ }^{32}$ In Vallicellianus F. 73, that is, as mentioned, considered the most trustworthy of the three manuscripts, a longer text follows that contains an allegorical commentary on the liturgy for Lent, Easter week and Easter itself, all explained against the background of the Babylonian captivity. This text, however, remains unpublished, ${ }^{33}$ but it is of the highest importance to understand the sense of the entire part of the Mirabilia within Benedict's Liber. It shows how liturgy has the capacity of resurrecting the past into the new and true life of Christ.

Besides, between the story on the Pantheon and the one on St. Peter in Vincoli, this same manuscript inserts as the only one of the three a historical introduction to the passion of Saint Lawrence, telling how the emperor Decius came to power by killing his predecessor, the Emperor Philippus and his son, who are both presented as Christians. ${ }^{34}$ They are the last emperors of Antiquity named. In what follows, their role will be overtaken by the pope.

After the dedication St. Peter in Vincoli follows the third part that consists of a huge enumeration of temples as they appear according to the Roman districts. It is notably this part that has aroused much criticism of scholars who have been looking for concrete information on the situation of Rome in this period. None of the temples mentioned seems to have ever existed, even when they are located in ruins or buildings of Antiquity that are known to have existed or that still can be seen. ${ }^{35}$

But, of course, Benedict did not want to give us an idea of the remnants of classical Rome in the 1140s. His idea of classical Rome is not even that of an imperial town. We can only read it as if he wants to depict it as a space that was already consecrated in pagan times. The urban surface of Rome simply seems not wide enough to contain all the temples bumping into each other. As such it was, according to the reading of the entire Liber as a coherent macro-

\footnotetext{
${ }^{30}$ Accame, Dell-Oro 2004, 110-127.

${ }^{31}$ Accame, Dell-Oro 2004, 126-149.

${ }^{32}$ Chapters 13 and 14: Accame, Dell-Oro 2004, 130-133.

${ }^{33}$ Fabre, Duchesne 1905-1910, vol. 1, 33: "Dans la partie conservée des Mirabilia, après le chapitre des colonnes (XXXVII) s'intercale sous le titre De ystoria ecclesiastica, un assez long commentaire sur les spécialités liturgiques du temps septuagésimal, de la semaine sainte et du temps pascal. C'est un tissu d'explications mystiques plus ineptes les unes que les autres. J'ai cru devoir laisser inédit ce morceau sans valeur aucune". [In the part of the Mirabilia that is conserved [in Vallicellianus F. 73], after the chapter on the columns (XXXVII), a rather long commentary is inserted under the title De ystoria ecclesiastica on the liturgical specificities of Lent, the Holy Week and Easter. It is a web of mystical explications of which the one is even more incongruous than the other. I did not think it worth to edit this piece without any value whatever]. In the meantime, I transcribed the fragment and hope to edit it as part of the entire reconstruction of Benedict's Liber.

${ }^{34}$ Fabre, Duchesne 1905-1910, vol. 1, 272-273.

${ }^{35}$ As has been demonstrated most clearly in Kinney 2008, 250-252.
} 
text, predestined to resurrect into the consecrated capital of Christianity. This is what all the stories indicate: they all treat the replacement of pagan rituals, festivities or temples by their Christian coronation. In a similar way, the head of the pagan consecrated space, the Emperor, had to disappear or even die in the person of the Christian Emperor Philippus, in order to make place for or rather revive as the pope, the Christian sovereign that surpasses all earthly power. $^{36}$

\section{By way of conclusion: Resurrecting the Past}

Benedict's Liber Polyptychus thus seems to answer to a clear and specific program which was just as political as it was spiritual. It gives a sound and balanced impression when considered in its entirety. That we have to take it as a unity, is proven also from another perspective. The first text, the Ordo, introduced by the dedication letter to Guido de Castello, closes upon the festivity of Saint Andrew without any concluding remarks. This is a bit peculiar. One would expect some words to recommend the writing to its addressee. Nothing of the like.

An equally strange fact, however, is shown by the Mirabillia. It simply starts with the description of the walls, without any introductory remarks. That ought not to raise any questions as none of the other preceding texts does either. But in contrast to those, the Mirabilia finishes on a very short conclusion, stating that all these temples and palaces were to be found in Rome as the author assures having read in old chronicles, seen with his own eyes and heard from the ancients. ${ }^{37}$ Here, he follows exactly the same lines and even uses some of the same or similar phrases as those that conclude the dedication letter, where Benedict guarantees that he had been eye-witness to all that he writes down in the Ordo or that he had heard it from the wise members of the Curia and read it in the books of the teachers of the Church. ${ }^{38}$ In both cases, in the dedication letter and in the final conclusion, the writer stresses that he wrote it down for the memory of future generations. ${ }^{39}$

\footnotetext{
${ }^{36}$ The same message seems conveyed by the not yet edited part in which the reconstruction of Jerusalem after the Captivity is described as a biblical prefiguration of Christ's death and resurrection.

${ }^{37}$ Fabre, Duchesne 1905-1910, vol. 1, 141: "Verumtamen, ut dixi, vestra dilectione et assidua pulsatione commotus, quod de dignitate Romani pontificis et presbiterorum cardinalium ac diaconorum ceterorumque ordinum curie necnon et de ecclesiastico officio tocius anni per multa temporum spatia vidi et a sapientibus curie audivi et quod alii doctores Ecclesie in suis scriptis reliquerunt, ad perpetue recordationis memoriam scribere curabo". [However, as I mentioned, I was moved by your love and continuous pressure. Therefore, I took care to write down for everlasting memory and recollection whatever there could be found on the dignity of the Roman pontifex, of the cardinal-priests, of the deacons and of all the other ranks of the Curia, as well on the ecclesiastical offices of the entire year. I have been able to see it all for a long time. I heard it from the wise ones in the Curia and found it written by other doctors of the Church].

${ }^{38}$ Fabre, Duchesne 1905-19010, vol. 1, 272: ch. 42; Accame, Dell-Oro 2004, 178-179: "Hec et alia multa templa et palatia imperatorum, consulum, senatorum prefectorumque tempore paganorum in hac Romana urbe fuere, sicut in priscis annalibus legimus et oculis nostris vidimus et ab antiquis audivimus. Quante etiam essent pulchritudinis, auri et argenti, heris et eboris pretiosorumque lapidum, scriptis ad posterorum memoriam quanto melius potuimus reducere curavimus". [These and many other temples and palaces of emperors, consuls, senators and prefects existed in pagan time sin the Roman city. We can read this in ancient annals and we have seen it with our own eyes and heard it from the ancients. All this beauty of gold and silver, of bronze and ivory, of the most precious stones, we took care to commit it all as good as we could to writing for the memory of those who come after us].

${ }^{39}$ Comparing both texts, one sees immediately that on both topics (the temples and palaces of Antiquity in the Mirabilia, the dignities, ordo and liturgy of the Roman ecclesiastics and year in the Ordo) Benedrict stresses that he tells what he has seen (vidi, vidimus), heard (audivi, audivimus) from the wise and ancient (a sapientibus curie, ab antiquis) and read in their writings (in suis scriptis, in priscis annalibus) and that he took care (curabo, curavimus) to write it down
} 
It thus seems that we have both an introduction and a conclusion to the Book as a whole. Remarkably, however, the introduction only regards the Ordo, while the conclusion only concerns the Mirabilia. Does this mean that they do not belong to each other? Rather, I would suggest that this shows clearly how both parts form two panels from different poles along the same axis. The first panel surpasses the second as its resurrected new image. They correspond to each other but not in a symmetrical way. We may compare it to the poetical diptych written some decades earlier by Hildebert of Lavardin, his minor poems 36 and 38. The first one, the best known, Par tibi Roma nihil, voices the admiration of a visitor confronted with the remnants of ancient Rome. Rome, however, answers in the other one, Dum simulacra mihi, and expresses her pride of being now the capital of Christianity. ${ }^{40}$

Elsewhere I have argued that Benedict's tour along the Roman temples must be read in view of the routes the different processions in the Ordo take. ${ }^{41}$ When mapping them both, it becomes immediately clear that almost all the temple areas are covered by the different processions during the year. The only exception is the Aventine but this hill is not described as an important temple area. And even there we can find liturgical links thanks to the enumeration of places where the martyrs suffered and died.

In Benedict's text, the Roman pagan universe thus becomes the foundation for a liturgical universe that serves the depiction of the pope as the successor and even transcendent resurrection of pagan (and contemporary?) emperors. Following Benedict on his tour along the fictional temples and places of antique worship we retrace the steps we already took while following him during the processions and on his transfers from one church to another. We just follow the same routes again and thus our memory will automatically record the splendour of papal processions while passing the now nude and silent ruins. They come to new life in the papal processions, in the liturgical ceremonies, in the pontifical chant.

Thanks to liturgy then, Rome becomes the town of Resurrection. Death in pagan Antiquity has become Life in the papal city. The Pope is the Resurrection of the antique Emperors. By the force of liturgy, he is capable to resurrect pagan Rome to its new Christian counterpart, papal Rome, which is the earthly representation of the celestial Jerusalem, of the heavenly Bride.

And that brings us back to the poor monk in the austere oratory of Clairvaux. This same pontifical splendour, these same pontifical chants, this liturgy so familiar to him in its essential points but so estranged in its concrete effect: it made the monk believe and experience a world unthought-of and unseen and gave him the impression to be reborn, to be resurrected into the mystic body of Christ. For a very short moment, the message Benedict's Book wants to pass to us became living truth in the overstrained imagination of a poor monk. And pagan Rome in its papal Resurrection was reborn in austere Clairvaux.

\section{Wim Verbaal}

University of Ghent

wim.verbaal@ugent.be

(scribere, scriptis reducere) for the memory of future generations (ad perpetue recordationis memoriam, ad posterorum memoriam). The parallels are too obvious to deny and surpass a casual or topical writing. The last sentence wants to echo the first one, thus creating a well-rounded unity of the entire Book.

${ }^{40}$ Scott 2001, 22-27.

${ }^{41}$ See also Kinney 2008. 


\section{PRIMARY SOURCES}

Accame M., Dell'Oro E. (tr.) 2004: I Mirbilia Urbis Romae. Tored, Roma.

Duchesne L. (ed.) 1892: Liber Pontificalis II. Thorin, Paris.

Dunbabin J. (tr.) Life of King Louis the Fat. St. Anne's College, Oxford OX2 6HS, England, at the Internet Medieval Source Book: https://sourcebooks.fordham.edu/basis/suger-louisthefat.asp (last consulted on October 25, 2018)

Fabre P., Duchesne L. (eds.) 1905-1910: Le Liber Censuum de l'église romaine. 2 vol. Fontemoing, Paris.
Heller J. (ed.) 1880: Aegidii Aureaevallensis Gesta episcoporum Leodiensium, MGH SS 25, Hahn, Hannover.

Scott A.B. (ed.) 2001: HIldebertus Carmina Minora. Teubner, Leipzig.

Valentini R., Zucchetti G. (eds.) 1946: Codice topografico della città di Roma, vol. 3. Istituto Storico Italiano per il Medio Evo, Roma, 17-65.

Verdeyen P. (ed.) 2011: Arnaldus Bonnaevallensis Vita prima sancti Bernardi Lib. II. In Paul Verdeyen (ed.), Vita prima sancti Bernardi Claraevallis abbatis, CCCM 89B, Brepols, Turnhout, 987-129.

Waquet H. (ed.) 1964: Suger. Vie de Louis VI le Gros. Les belles Lettres, Paris.

\section{SECONDARY LITERATURE}

Astell A.W. 2006: Eating Beauty: The Eucharist and the Spiritual Arts of the Middle Ages, Ithaca.

Champagne M.Th., Boustan R. 2011: "Walking in the Shadows of the Past: The Jewish Experience of Rome in the Twelfth Century", Medieval Encounters 17, 464-494.

Dyer J. 2008: "Roman Processions of the Major Litany (litaniae maiores) from the Sixth to the Twelfth Century", in Ó Carragáin, Éamonn, Neumann de Vegvar, Carol (eds.), Roma Felix - Formation and Reflections of Medieval Rome, London, 113-137.

Fossier R. 1953: "L’installation et les premières années de Clairvaux", in Commission d'histoire de l'ordre de Cîteaux (ed.), Bernard de Clairvaux. Préface de Thomas Merton. Paris, 77-93.

Hamilton L. 2011: "The Rituals of Renaissance: Liturgy and Mythic History in The Marvels of Rome", Medieval Encounters 17, 417-438.

Haseldine J. 1997: "The Creation of a Literary Memorial: The Letter Collection of Peter of Celle", SEJG 37, 333-379.

Haseldine J. (ed.) 2001: The letters of Peter of Celle, Oxford.

Kinney D. 2008: "Fact and Fiction in the Mirabilia Urbis Romae", in Ó Carragáin, N. Éamonn, C. de Vegvar (eds.), Roma Felix - Formation and Reflections of Medieval Rome, London, 235-252.
Miedema N.R. 1996: Die “Mirabilia Romae”: Untersuchungen zu ihrer Überlieferung mit Edition der deutschen und niederländischen Texte, Tübingen.

Riccioni St. 2011: "Rewriting Antiquity, Renewing Rome. The Identity of the Eternal City through Visual Art, Monumental Inscriptions and the Mirabilia", Medieval Encounters 17, 439-463.

Romano J. 2010: "The Ceremonies of the Roman Pontiff: Rereading Benedict's Twelfth-Century Liturgical Script", Viator 41, 2010, 133-150.

Rouse M., Rouse R.H. 1991: Authentic witnesses: approaches to medieval texts and manuscripts, Notre Dame.

Saenger P. 1977: Space between words: the origins of silent reading, Stanford.

Santi M. 2014: "Performative Perspectives on Short Story Collections", in E. D'Hoker, B. Van den Bossche (eds.) Interférences littéraires / Literaire interferenties 12: Cycles, Recueils, Macrotexts: The Short Story Collection in Theory and Practice, 145154.

Schimmelpfennig B. 1973: Die Zeremonienbücher der römischen Kurie im Mittelalter, Tübingen.

Vacandard E. 1927: Saint Bernard, abbé de Clairvaux, Paris.

Verbaal W. 2014: "Trapping the Future: Abelard's Multi-layered Image-building”, in B. Hellemans 
(ed.), Brills Studies in Intellectual History, Leiden, 187-212.

Verbaal W. 2015: "Epistolary Voices and the Fiction of Literature", in Ch. Høgel, E. Baroli (eds.), Medieval Letters. Between Fiction and Document. Utrecht Studies in Medieval Literacy 33, Turnhout, 9-31.

Verbaal W. 2017: "Voicing your Voice: The Fiction of a Life. Early Twelfth-Century Letter Collections and the Case of Bernard of Clairvaux", Interfaces 4: https://riviste.unimi.it/interfaces/article/view/7620, 103-124.

Verbaal W. 2018: “Authors' Collections and an Author's Book: a Feasible Distinction? The Loire Poets as Case Study", Atti del convegno SISMEL 2017: Collezioni d'autore nel Medioevo, Firenze, 121-135. von Moos P. 2006: "Briefkonventionen als verhaltensgeschichtliche Quelle", in P. von Moos, G. Melville, Rhetorik, Kommunikation und Media-lität, Berlin, 173-203.

Waddell C. 1984: The Twelfth-Century Cistercian Hymnal. Cistercian Liturgy Series 1, Cistercian Studies, Kalamazoo.

Ysebaert W. 2009: "Medieval letters and letter collections as historical sources: methodological questions and reflections and research perspectives (6th-14th centuries)", Studi Medievali 50, 41-73. Reprinted in Ch. Høgel, E. Baroli (eds.), Medieval Letters. Between Fiction and Document. Utrecht Studies in Medieval Literacy 33, Turnhout, 33-62. 